\title{
Using Online Lexicons as Sources of Domain-specific Terminology in Translation
}

\author{
Svitlana Amelina ${ }^{1,{ }^{*}}$ Rostyslav Tarasenko ${ }^{2}$ Vasyl Shynkaruk ${ }^{3}$ \\ ${ }^{I}$ National University of Life and Environmental Sciences of Ukraine, Ukraine \\ *Corresponding author. Email: svetlanaamelina@ukr.net
}

\begin{abstract}
The paper focuses on the use of online lexicons in the translation process. A number of online lexicons containing agricultural and environmental terminology are considered. It analyses the ways in which translators use online lexicons and finds that they can be a source of terminological and supplementary information. Comparisons have been made between the printed and online versions of the lexicons and a number of advantages of the online lexicons have been identified. The continual updating of the entries in the online lexicons and the increasing amount of data contained in them were found out. The usefulness of hyperlinks, which allow the use of not only one particular lexicon but also other related Internet sources, is highlighted.
\end{abstract}

Keywords: domain-specific terminology, online lexicon, terminological resource, translator.

\section{INTRODUCTION}

The term "lexicon" comes from the ancient Greek "dictionary" and is a reference book or dictionary in the broad sense [1]. In addition, this term has sometimes previously been used synonymously with linguistic vocabulary. In the modern sense, a lexicon is mainly seen as a factual reference book. A distinction is made between a lexicon in the narrow sense and an encyclopaedia, depending on its volume. From a lexicographic perspective, a distinction is also made between a dictionary as a source of linguistic information and a lexicon as a collection of information.

Given the history of the emergence and development of such a category of publications as lexicons, it is worth noting that they existed mainly in the printed version. Now lexicons also have numerous websites that present different types of information. The main content of the lexicon in book form is divided into articles, while the online versions of the lexicons have separate web sites.

The articles in the printed lexicons are not arranged alphabetically and by index, but are organised alphabetically according to their key words. The key word is at the beginning of the entry and is separated from the text of the entry in a certain way. The function of keywords in online vocabularies is performed by headings, and the required information searched for can be found using the programmed internal search functions or via internet search engines.

In its current general application, a vocabulary is usually understood as a collection of data that deals not only with general knowledge topics, but also explains specialised topics in detail (e.g. vocabularies of various specialisations - political, economic, computer, agricultural, etc.).

The purpose of this paper is to consider the use of online lexicons when translating texts on agricultural fields from German into Ukrainian.

\section{LITERATURE REVIEW}

There is still no consensus among linguists and lexicographers on the essence and purpose of lexicons. Therefore, many studies are devoted to clarifying their content, the difference from dictionaries and glossaries, and the scope of their use.

K. Emmorey, V. Fromkin consider the lexicon as a mental phenomenon and state that the mental lexicon is that component of the grammar that contains all the information - phonological, morphological, semantic, and syntactic - that speakers know about individual words and/or morphemes [2]. According to F. Sowa, the lexicon is the bridge between a language and the knowledge expressed in that language [3]. 
However, attempts have already been made to consider online lexicons as an important supplementary element in the process of learning foreign languages, and in particular in the training of translators $[4,5,6]$.

S. Nielsen, noting the importance of lexicographic resources, suggests using lexicographic, factual and linguistic approaches to analyse the available print and electronic versions of dictionaries [7].

The importance of studying dictionaries and lexicons not only in the theoretical aspect but also in the applied aspect, as well as the analysis of the applicability of their different types in foreign language learning and translation, is noted in a number of publications $[8,9,10]$.

\section{RESULT AND DISCUSSION}

\subsection{Agricultural lexicons as an example of a subject-specific terminological resource}

The online Wiki-Agrar-Lexikon [11] is a complete collection of German-language agricultural terminology and contains explanations of allimportant terms used in the agricultural and environmental sectors. It is based on IMAAgrilexikon. Agrilexikon is designed as a knowledge base from the agricultural sector that is aimed at different categories of consumers - those directly involved in agricultural production as well as teachers and students. Explanations of key words are provided in the text in the figures. Additional references point to other sources of information, brochures or manuals, which can be ordered as hard copies. Graphs and figures can be downloaded and used as worksheets and templates.

With its comprehensive information coverage of the concepts presented, the online Agrilexikon can provide all users with a basic knowledge and understanding of the processes involved in modern agriculture.

By searching, for example, for the term "Raufutter" ("roughage") in the Wiki-Agrar-Lexikon online lexicon (Fig. 1), the following information can be obtained:

\section{Roughage}

Also called staple fodder or farm fodder, cover both water-rich fodder (green fodder) and other sap fodder such as beet or silage, as well as dry coarse fodder such as hay or straw. Staple feed is voluminous and generally has a lower market and feed value and poor transportability. It is usually produced locally.
However, this is not sufficient for a balanced performance-based diet and should therefore be combined with concentrated feed (compound feed) so that the feed input per unit of performance (e.g. litres of milk) remains as low as possible while making optimum use of the animal's productivity [11].

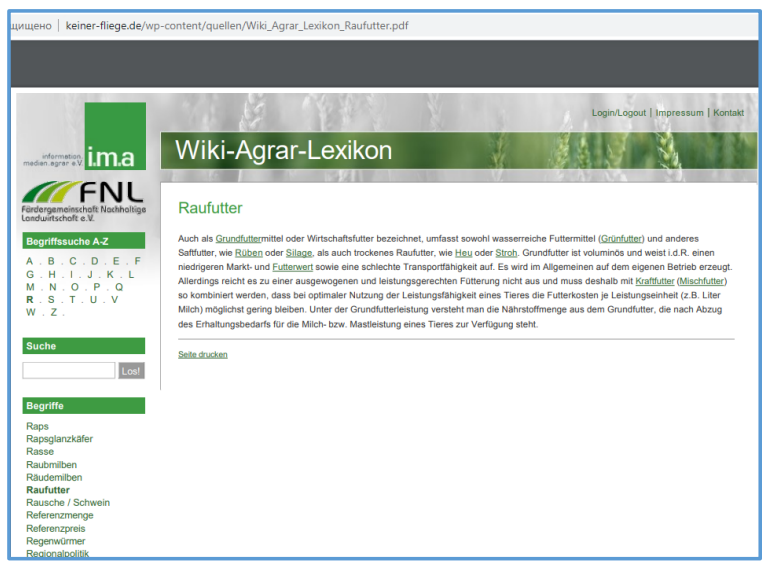

Figure 1 Search results for "Raufutter" in the online lexicon Wiki-Agrar-Lexikon.

Of particular note is C. Baldenhofer's Lexikon des Agrarraums (Fig. 2), the first version of which was a print edition, and since 2017 it has been available in online format. As its name indicates, the lexicon is focused in its content on agricultural areas and other related issues - their condition, agricultural production on these areas, conservation, and the like. According to the author of the lexicon [12], agricultural areas are the largest part of the land that people value. In their diversity, they represent a wide variety of natural conditions and human cultural and social activities. The analytical overview of the agricultural sector is carried out by many social groups, national and transnational companies, organisations and political entities, and is a concern of scientific specialised subjects. In this aspect, the lexicon with the relevant keywords covers a wide range of spheres of influence in agricultural areas, with a certain predominance of the agrarian geographical perspective. The spatial focus is predominantly on Central Europe.

Almost 20 years have passed since the publication of the printed edition of the Lexikon des Agrarraums. Much of the content of this edition was already outdated and needed updating and supplementing for the new edition, which was carried out by the author. In doing so, the author has added a significant number of new keywords. The result of this browsing is now presented digitally on the internet and can be freely used for non-commercial purposes. The digital format has significant advantages over the print version, as it allows for rapid correction and addition of content. 
Such an update is necessary given changes in, for example, agricultural policy and the large number of new publications on agricultural subjects.

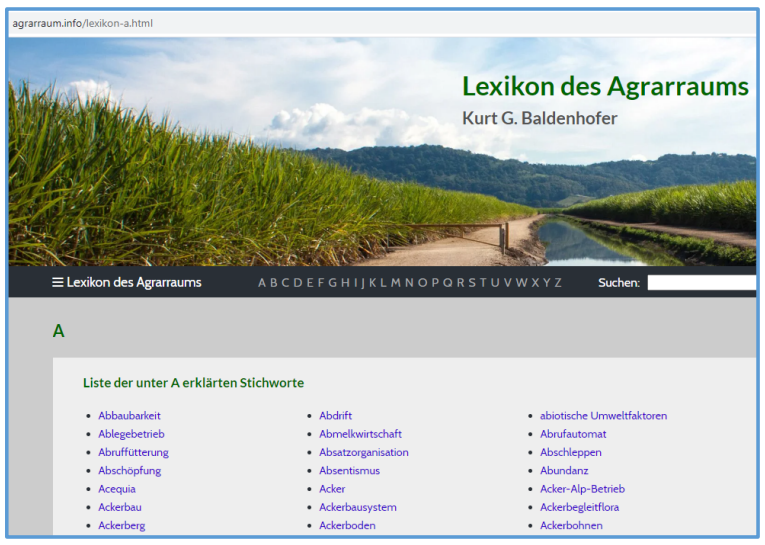

Figure 2 Lexicon "Lexikon des Agrarraums".

The target group of the lexicon is primarily students of agricultural and natural sciences, agricultural geography and other related sciences as well as economics. Of course, the information presented in the lexicon is also useful, as the author notes, for the relevant authorities, journalists, and in general, for anyone who deals with agriculture professionally or privately. However, we see significant potential for this lexicon in the sense of a terminological source that can be used by translators in the process of translating texts related to various issues of agricultural production.

A search for the keyword "Weizen" ("wheat") yields a variety of information about the crop, as shown in Fig. 3. The data presented contain primarily general information on wheat, namely the name of a number of plant species of the sweet grass (Poaceae) genus Triticum L.; two species are mainly cultivated common wheat (Triticum aestivum) and durum wheat (Triticum durum). The different species of wheatgrass reach a height of about 0.5 to $1 \mathrm{~m}$. The stem is rounded. A thousand grains weigh 40-65 grams. A spikelet contains a maximum of four grains. There are thousands of varieties of wheat in the world, each with different requirements for climate and soil.

Besides general information, the lexicon describes in detail the use (Verwendung), cultivation (Anbau), origin (Herkunft) of wheat. Some of the data are illustrated for clarity in graphs, as shown in Fig. 4.

Users are offered several links that can be clicked on to find out more about certain specific subjects and issues related to the crop. In particular, it is the current wheat price situation (Fig. 5), statistical data on the state of world wheat trade. One of the links takes one to Klett's website, where an information sheet on wheat (Fig. 6) can be downloaded in pdf format and used, for example, in the educational process or directly in translation. On the basis of the materials received, the translator is able on the one hand to acquire the necessary knowledge of the subject of the translation, and on the other hand to use the specialist terminology contained in the texts presented.

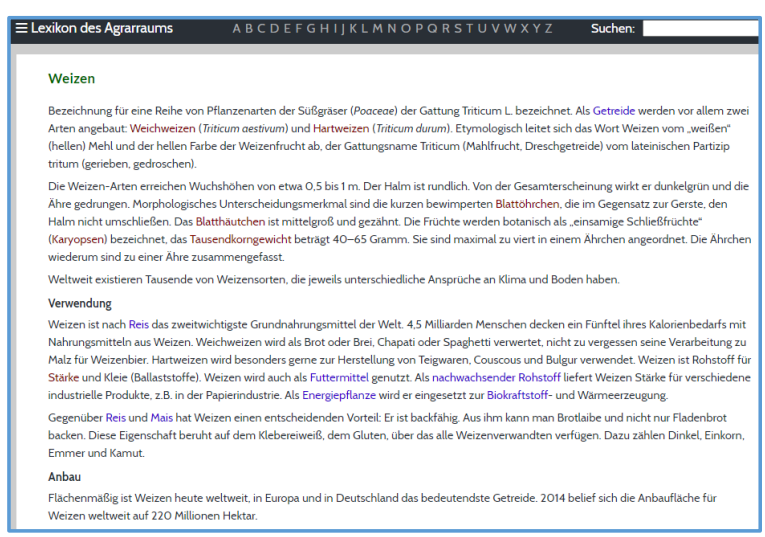

Figure 3 Data search result for the keyword "Weizen" in the Lexikon des Agrarraums.

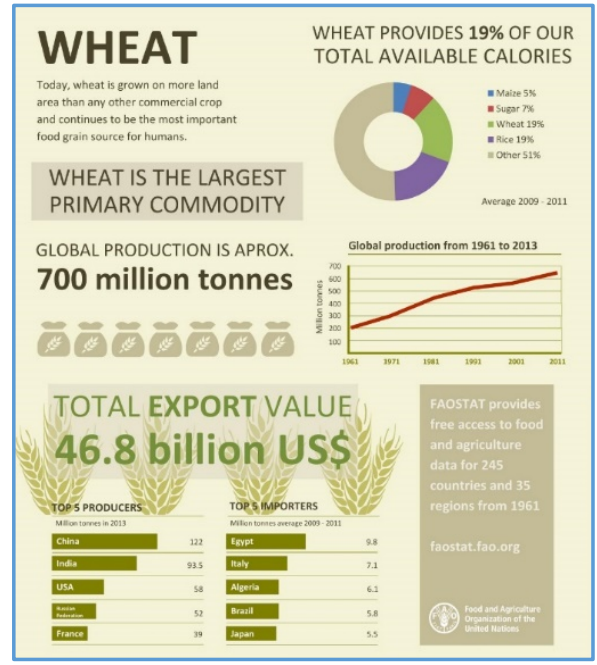

Figure 4 Graphic information for the key word "Weizen" in Lexikon des Agrarraums.

The "Agrarlexikon mit den wichtigsten Begriffen zur Landwirtschaft im europäischen Umfeld" ("Agricultural lexicon with the most important agricultural terms in the European environment") (Fig. 7) was created by M. Raupp [13] as part of the integrated BIOFECTOR project under the European Union, which aims to develop new approaches for the use of so-called biofectives. These living microorganisms and natural active ingredients can promote healthy growth, nutrient uptake and resistance of cultivated plants to abiotic and biotic stressors. These bioeffectors can be used to increase 
productivity and improve the utilisation of nutrients from alternative fertilisers, for example in organic farming. A strategic combination of alternative feeding strategies with bioequivalent products specifically adapted to the respective prevailing conditions can help to reduce agrochemical use and promote sustainable and environmentally friendly agricultural production.

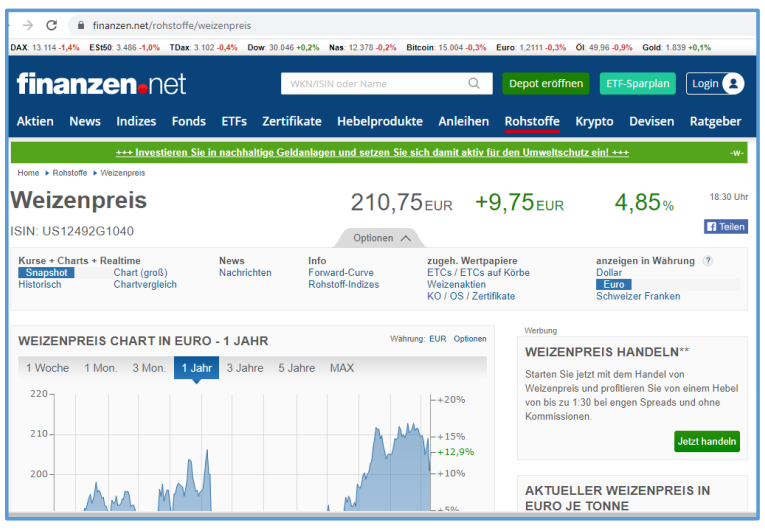

Figure 5 Wheat prices on the website

https://www.finanzen.net/rohstoffe/weizenpreis

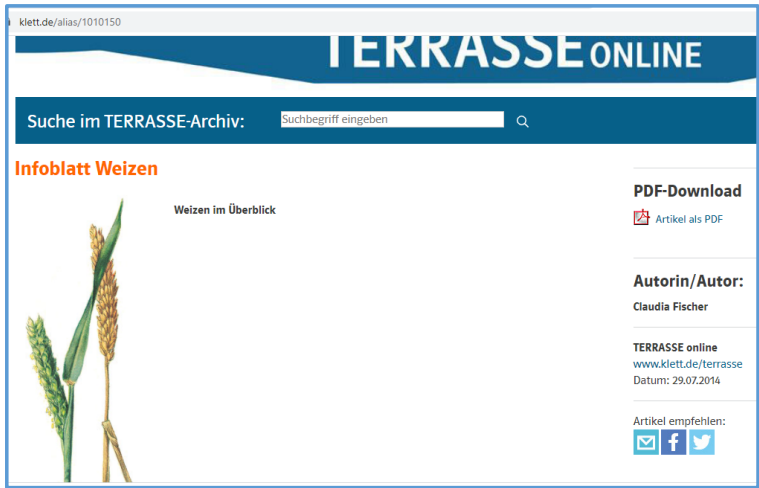

Figure 6 Wheat factsheet on the Klett Publishers website.

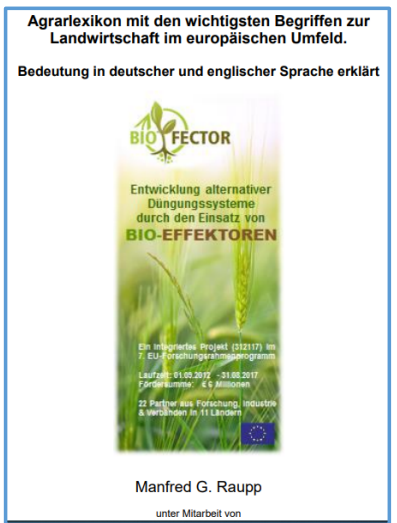

Figure 7 The lexicon "Agrarlexikon mit den wichtigsten Begriffen zur Landwirtschaft im europäischen Umfeld".

\subsection{Using lexicons by translators for additional information}

For translators, this lexicon is not only useful as a monolingual source of terminology that contains important terms for organic agriculture with an appropriate commentary-explanation. Since the terms and their explanations are in German and English, this allows the translator to compare them and use them when translating the relevant professional texts. Let us take the term "Ackerkrume" as an example (Fig. 8).

"Ackerkrume wird die lockere oberste Schicht eines Ackers genannt; hier finden sich viele Lebewesen die Wurzeln und Pflanzenreste zu Humus verarbeiten. In der Krume finden die Pflanzenwurzeln ihren Halt und in Wasser gelöste Pflanzennährstoffe, die man als Dünger ersetzt.

Topsoil is the term for the loose upper layer of soil in a field, where many organisms process roots and plant detritus to humus. Plant roots fins a footing in this crumbly textured earth, and also take up watersoluble nutrients which are natural fertilizer".

“Орним шиаром трунту називається пухкий верхній шар трунту; тут знаходяться багато живих істот, які переробляють коріння та рослинні залишки у перегній. Ця розсипчаста фактура землі є опорою для коріння рослин, тут містяться водорозчинні поживні речовини, які використовують як природне добриво”.

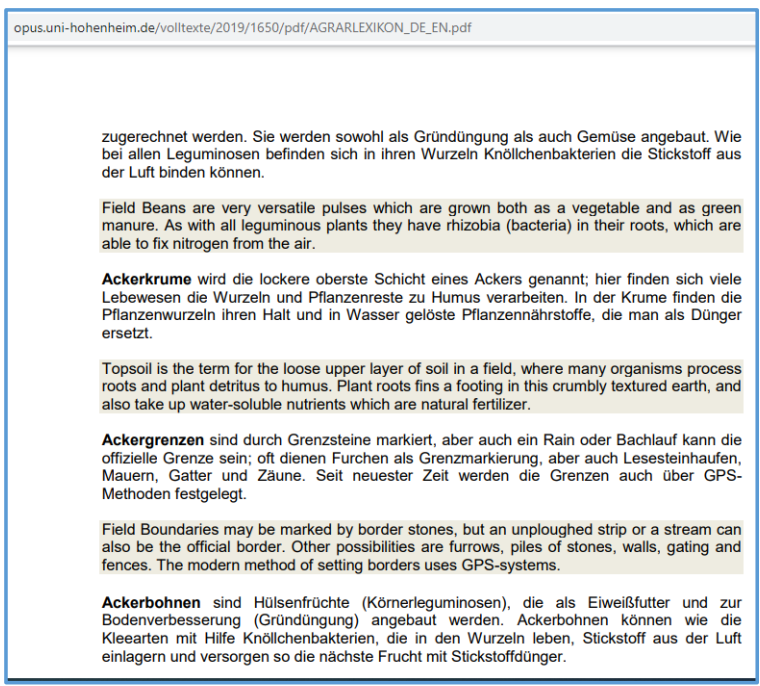

Figure 8 Search results for "Ackerkrume" in the lexicon "Agrarlexikon mit den wichtigsten Begriffen zur Landwirtschaft im europäischen Umfeld"

The Proplanta Information Centre has placed the Agrar-Lexikon separately on its website (Fig. 9) and separately a number of dictionaries, in particular the 
Dictionary of Agricultural Terms. We will look at their structure and content to determine the differences and possibilities of use by translators.

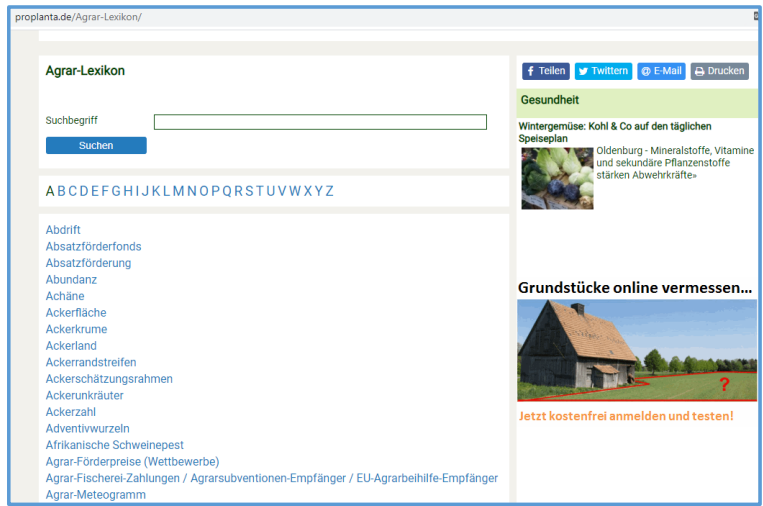

Figure 9 The Agrar-Lexikon on the Proplanta Information Centre website.

A search of the Agrar-Lexikon for the term "Ackerkrume" gives the result shown in Fig. 10.

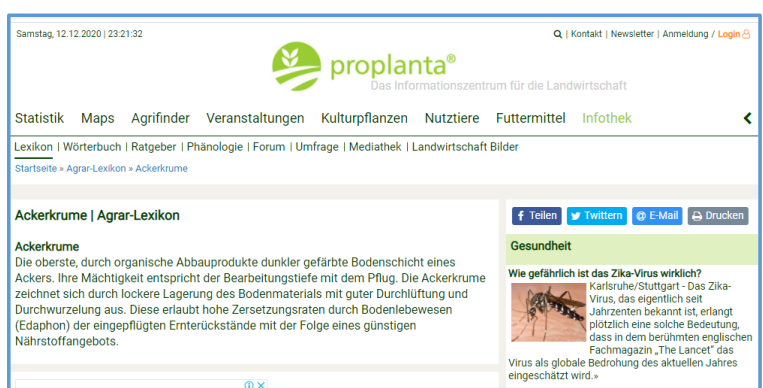

Figure 10 Search results for the term "Ackerkrume" in the Agrar-Lexikon

\section{“Ackerkrume}

Die oberste, durch organische Abbauprodukte dunkler gefärbte Bodenschicht eines Ackers. Ihre Mächtigkeit entspricht der Bearbeitungstiefe mit dem Pflug. Die Ackerkrume zeichnet sich durch lockere Lagerung des Bodenmaterials mit guter Durchlüftung und Durchwurzelung aus. Diese erlaubt hohe Zersetzungsraten durch Bodenlebewesen (Edaphon) der eingepflügten Ernterückstände mit der Folge eines günstigen Nährstoffangebots".

\section{“Орний шар трунту}

Найвищий шар трунту поля, затемнений органічними продуктами розкладання. Його товщчна відповідає глибині обробітку плугом. Для орного шиар трунту характерним є вільний стан трунтового матеріалу з хорошою вентиляиією та вкоріненням рослин. Це дозволяє забезпечити високі темпи розкладання трунтовими організмами (Едафон) заораних залишків врожаю, щуо призводить до сприятливого забезпечення поживними речовинами”.

Some of the entries offered by the Proplanta Information Centre are accompanied not only by a description, but also by photographs or illustrations for better illustration; for example, on the subject of "Mais / Maisanbau" (Fig. 11).

A detailed description of maize data (Mais) covers a wide range of issues relating to this crop - market information (prices), cultivation, pests and their manifestations, symptoms of maize damage, plant protection products with recommendations specifically for maize, general data on maize (biological characteristics, distribution history, statistics, etc.). A valuable feature is that additional information can also be obtained from other sources by clicking on the hyperlink, the user receives a list of literature on the topic, as well as a separate list of professional publications.

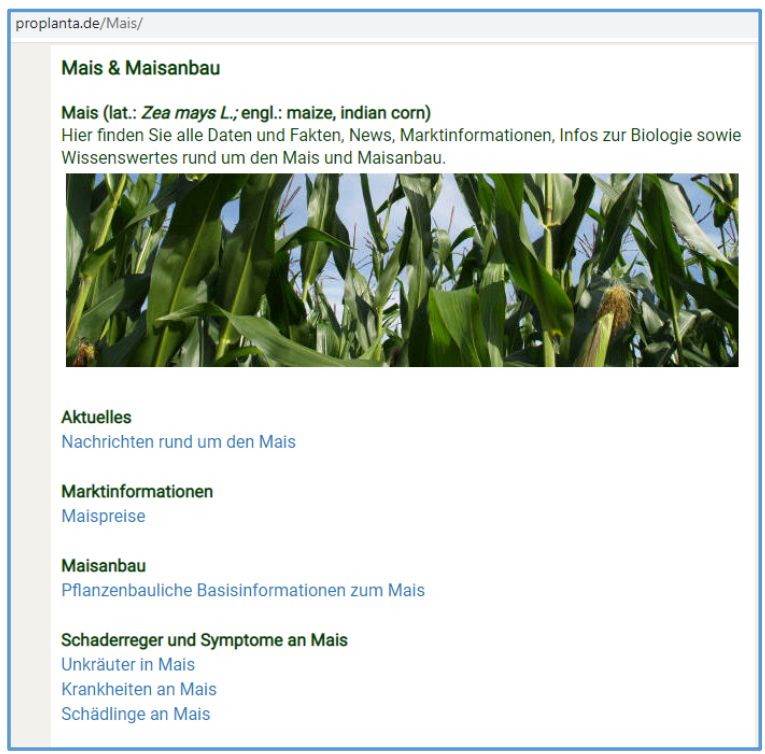

Figure 11 Search results for "Mais / Maisanbau"

The "Wörterbuch der Landwirtschaft" ("Dictionary of agricultural terms") of the Proplanta Information Centre is shown in Fig. 12.

As we can see, unlike the lexicon, the dictionary of agricultural terms contains only the term and its correspondence (in our case the German term and its correspondence in English). The other dictionaries on this website - Wörterbuch der Landtechnik, Wörterbuch der Pflanzenkrankheiten, Wörterbuch der Pflanzenschädlinge, Wörterbuch der Unkräuter, Wörterbuch der Nutztiere, and Wörterbuch der Tiergesundheit - have the same structure and content. The latter is shown in Fig. 13. 


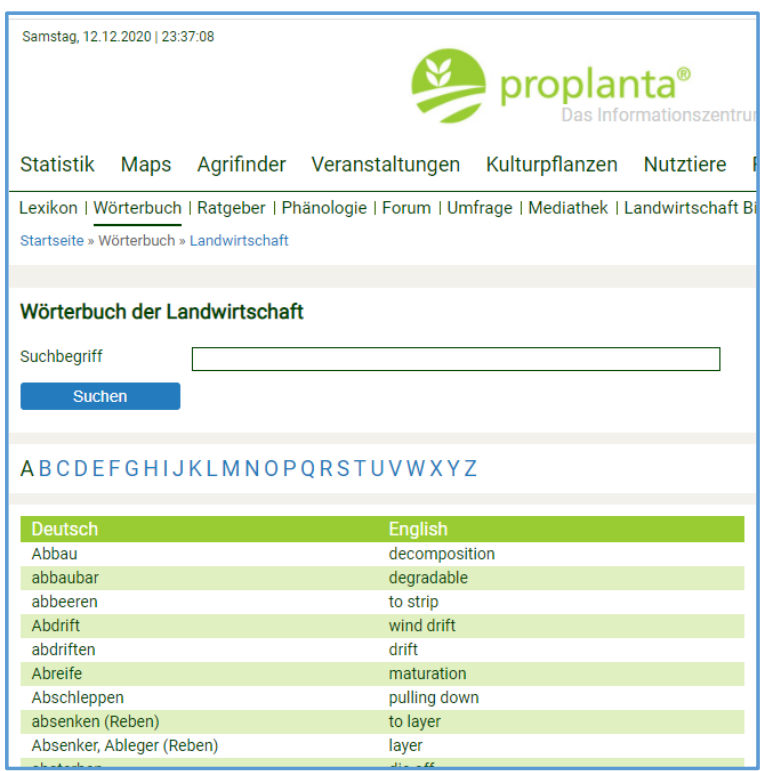

Figure 12 "Wörterbuch der Landwirtschaft" on the Proplanta Information Centre website

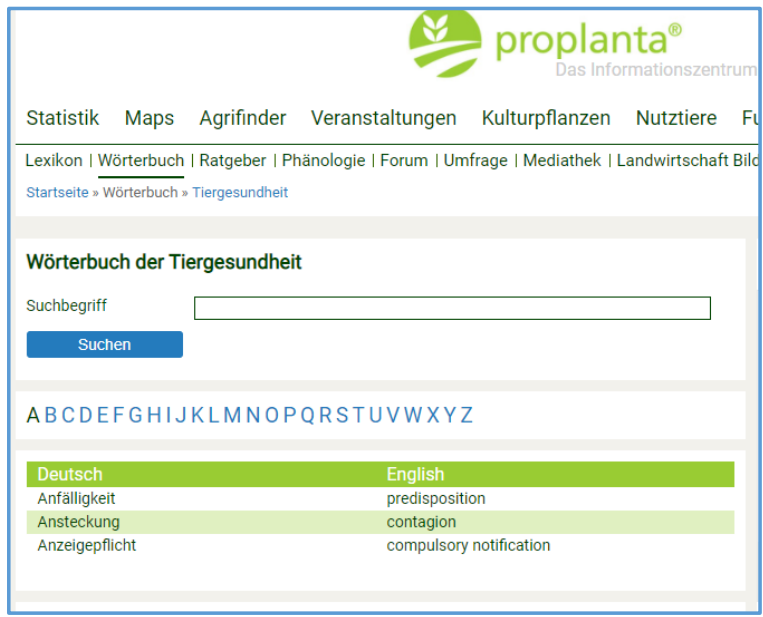

Figure 13 Dictionary "Wörterbuch der Tiergesundheit" on the Proplanta Information Centre website

Each of the Proplanta Information Centre's specialised dictionaries offers a different number of terms from the relevant field, and the list is far from exhaustive. Therefore, despite the inherent richness of terms in professional texts, it is advisable to take into account the need for additional use of other terminology resources when translating, as the content of Proplanta dictionaries will not be sufficient.

Particularly useful for translators in the agricultural, environmental and food-processing industries, i.e. all areas in which documents and other textual material are in one way or another associated with agricultural style is a highly specialised lexicon. Thanks to these lexicons, translators are able to reproduce the source text with a high level of equivalence, since the use of terminology containing the lexicons helps to determine an adequate correspondence in the target language and then to reflect the information of the source text in detail in the translated text.

An example of such a lexicon would be "Lexikon. Waldschädigende Luftverunreinigungen und Klimawandel" ("Lexikon. Air pollution harmful to forests and climate change") [14], which exists in parallel in two versions - print and online.

The online version of the Vocabulary (Fig. 14) contains over 4,800 relevant keywords with crossreferences and English translations, some of them clearly illustrated with tables and figures.

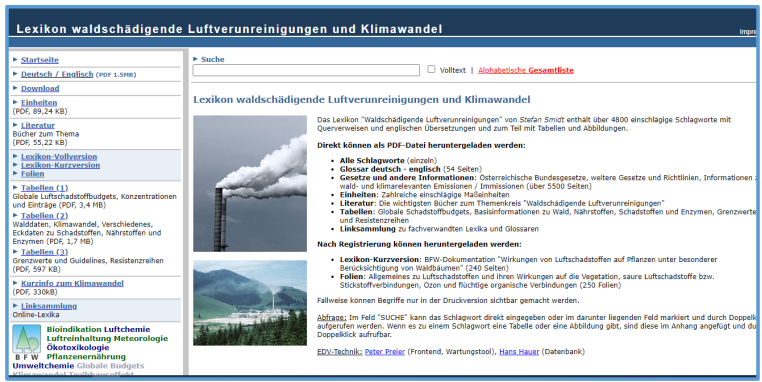

Figure 14 Main site of the lexikon "Lexikon. Waldschädigende Luftverunreinigungen und Klimawandel"

\subsection{Comparison of online and printed versions of lexicons}

Some of the materials contained in or hyperlinked to the lexicon can be downloaded freely, without registration or payment, as a PDF file, as follows:

- a list of all keywords;

- German-English glossary;

- laws and other useful and up-to-date information - directives, emissions data, in particular related to forests and climate;

- measurement units;

- sector specific literature (the most important books on harmful air pollution for forests);

- tables with data on global pollutant indicators; basic information on forests, nutrients, pollutants and enzymes, limit values of substances, etc.;

- a list of links to related lexicons and glossaries.

Certain additional features are offered if the user registers. After registration, it is possible to download: 
- a short version of the lexicon "Wirkungen von Luftschadstoffen auf Pflanzen unter besonderer Berücksichtigung von Waldbäumen" ("Effects of air pollutants on plants with special consideration of forest trees"), which is 240 pages long;

- slides with general information on air pollutants and their effects on vegetation, acidic air pollutants and nitrogen compounds, ozone and volatile organic compounds.

As we are looking at the use of lexicons as terminological sources, it is logical to explore in more detail which particular lexicons can be accessed through hyperlinks from the lexicon list (Fig. 15). This list contains various dictionaries, glossaries and vocabularies with domain-specific terminology, such as botany, cytology, domain legislation, wood, environment, pollutants, chemistry, climate change and protection, water, geo-informatics, energy, biotechnology, meteorology, etc.

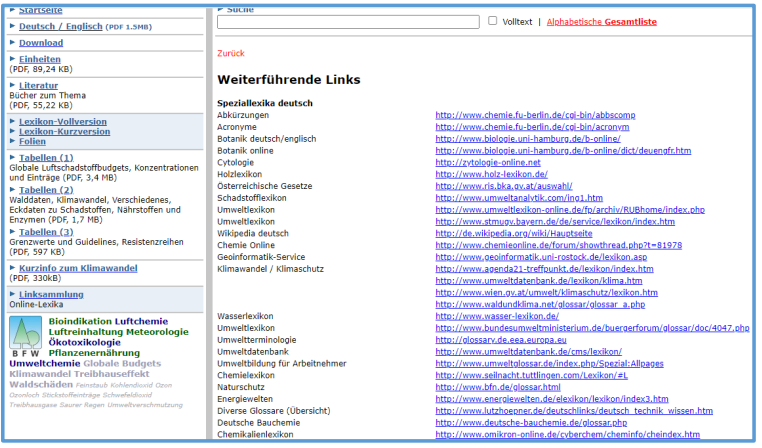

Figure 15 List of links to lexicons on the website "Wirkungen von Luftschadstoffen auf Pflanzen unter besonderer Berücksichtigung von Waldbäumen”.

By clicking on the glossary or lexicon favourite's link, you navigate to it and can use the information from this terminology resource, as shown in Fig. 16 and Fig. 17. By comparing them, it can be concluded that there is diversity in the way information is presented in these sources. Fig. 16 shows the lexicon "Umweltlexikon" ("Environmental lexicon"). It is presented as a collection of entries on issues related to the environment, which are accompanied by illustrations. Therefore, the translator can use this material as a reference since he/she is not an expert in the field he/she is translating from and therefore often requires additional information regarding the subject matter of the translation. The presence of photos, tables, graphs, etc. helps to better understand the material.

After moving on to another lexicon, the "HolzLexikon" ("Wood Lexicon") can be used as an explanatory dictionary of the terms it contains. There are brief definitions and explanations, without extensive comments or illustrations. For example:

“Ast: Eine Seitenachse der Baumachse (Stamm) des Baumes. Äste tragen als feinere Auszweigungen die Zweige, deren jüngste Triebe genannt werden. Äste und Zweige zusammen bilden die Baumkrone. Äste sind die wichtigsten Merkmale der Gütesortierung von Rund- und Schnittholz. Bei Schnittholz sind Äste die vom weiterwachsenden Holzgewebe eingeschlossenen Teile ehemaliger Äste (siehe auch Durchfallast, Schwarzast, Verwachsener Ast, Flügelast, Punktast, Astquirl)”.

“Гілка: бічна вісь осі дерева (стовбура) дерева. Гілки містять більи тонкі гілочки, найменші $з$ яких називаються пагонами. Гілки та гілочки разом утворюють крону дерева. Гілки $\epsilon$ найважливішими характеристиками якісного сортування круглої та пиляної деревини. У випадку з пиляною деревиною гілки - ие частини колишніх гілок, укладені деревною тканиною, яка продовжує рости (див. також роговий сучок, чорний сучок (незрощений сучок), зрощений сучок, ламчатий сучок, шпильковий сучок, мутовчатий сучок)".

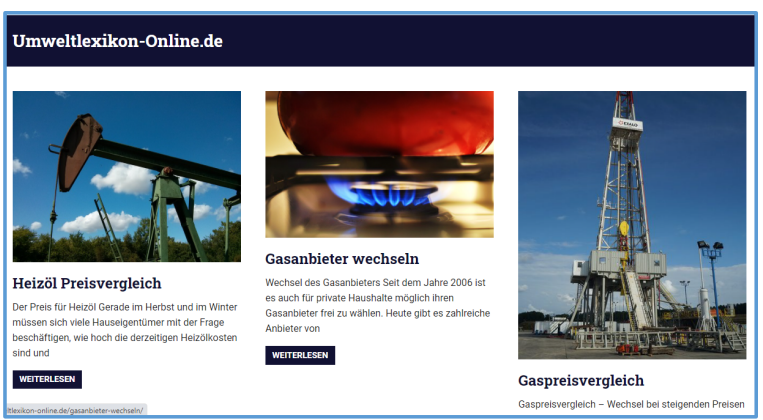

Figure 16 The lexikon "Umweltlexikon".

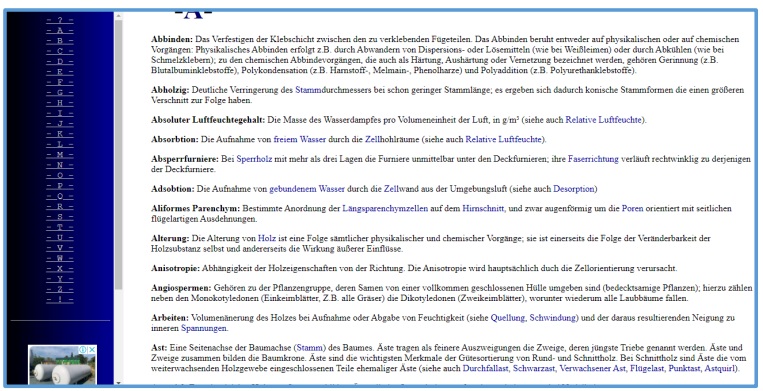

Figure 17 The Lexikon "Holz-Lexikon".

Although the Holz-Lexikon provides only brief descriptions of keywords, their more detailed explanations can be found by clicking on the corresponding active hyperlinks, which are available for almost all-important terms. 
Terminological resources are presented somewhat differently in other lexicons, e.g. the Chemielexicon (Fig. 18 and 19).

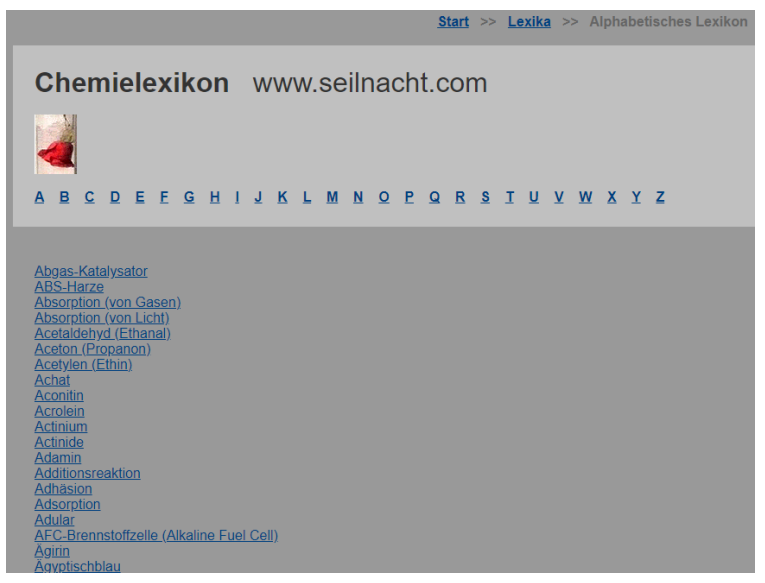

Figure 18 The lexikon "Chemielexicon".

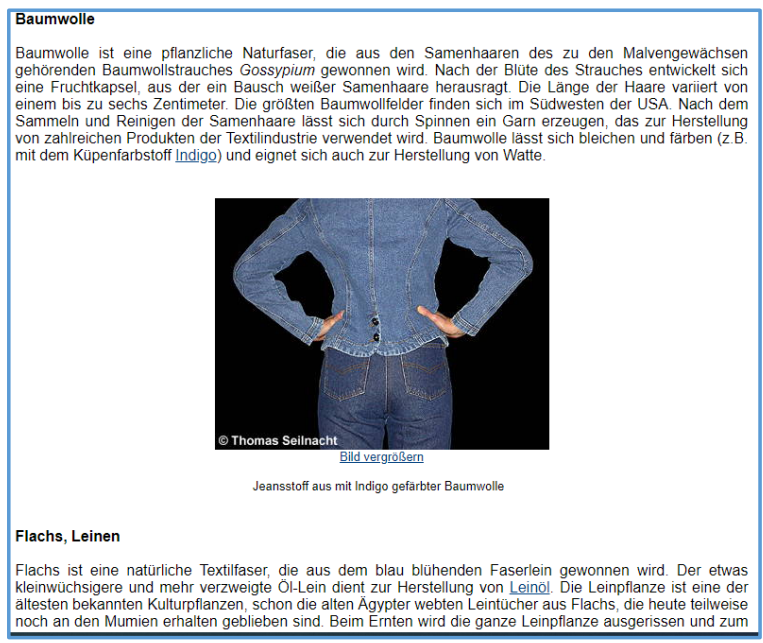

Figure 19 The entry "Baumwolle" in the Chemielexicon

A search for the required term in the Chemielexicon is made using keywords presented in alphabetical order, as shown in Fig. 19. Once we have selected a certain term (in our example "Baumwolle" ("Cotton"), we click on the relevant link to an entry on the selected subject or concept. The entries often contain illustrations or photos, which are clearly textual explanations.

\section{Baumwolle}

"Baumwolle ist eine pflanzliche Naturfaser, die aus den Samenhaaren des zu den Malvengewächsen gehörenden

Baumwollstrauches Gossypium gewonnen wird. Nach der Blüte des Strauches entwickelt sich eine Fruchtkapsel, aus der ein Bausch weißer Samenhaare herausragt. Die Länge der Haare variiert von einem bis zu sechs Zentimeter. Die größten Baumwollfelder finden sich im Südwesten der USA. Nach dem Sammeln und Reinigen der Samenhaare lässt sich durch Spinnen ein Garn erzeugen, das zur Herstellung von zahlreichen Produkten der Textilindustrie verwendet wird. Baumwolle lässt sich bleichen und färben (z.B. mit dem Küpenfarbstoff Indigo) und eignet sich auch zur Herstellung von Watte”.

\section{Бавовна}

“Бавовна - це натуральна рослинна клітковина, яку отримують із насіннєвих волосків бавовняного кущал Gossypium, щуо належить до сімейства мальвових. Після того, як кущ зацвів, розвивається плодова капсула, з якої виступає пачка білого насіннєвого волокна. Довжина волокна варіюється від одного до шести сантиметрів. Найбільші бавовняні поля знаходяться на південному заході США. Після того, як насіннєві волокна зібрані та очищені, шляхом прядіння може бути отримана пряжа, щุо використовується для виробництва численних виробів у текстильній промисловості. Бавовна може бути вибіленою та пофарбованою (наприклад, кубовим барвником індиго), а також підходить для виготовлення вати”.

The lexicon "Zytologie" ("Cytology") is designed in such a way that a search for an explanation to the required term must be done by using it as a key word through the glossary, where terms are presented in alphabetical order (Figure 20).

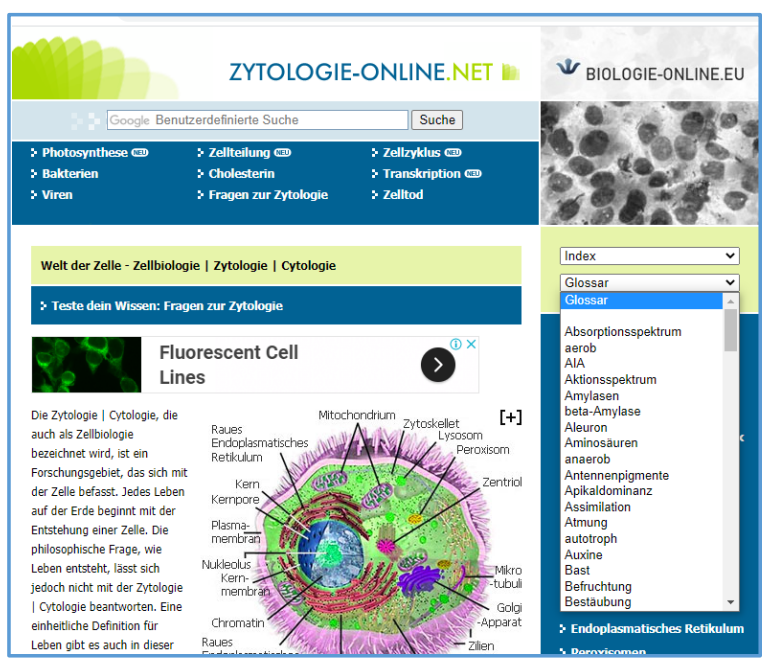

Figure 20 The lexikon "Zytologie".

A search for the term "Atmung", for example, brings up the short explanatory entry below.

\footnotetext{
Atmung

“(genauer: Zellatmung) Die Dissimilation
} 
organischer Stoffe (vor allem von Kohlenhydraten) zu Kohlendioxid und Wasser (chemische Gleichung der Veratmung von Traubenzucker [Glucose]. Bei diesem Stoffabbau durch Oxidation gewinnt die Zelle einen bedeutenden Energiebetrag. Gleiche Wirkung in geringerem Grad Gärung”.

\section{Дихання}

"(Точніме: клітинне дихання). Дисиміляція органічних речовин (насамперед вуглеводів) до вуглекислого газу та води (хімічне рівняння втрати на дихання виноградного иукру [глюкози]. Під час ивого розщеплення речовин иляхом окислення клітина отримує значну кількість енергії. Той самий ефект при нижчому ступені ферментаиії”.

As we can see, the explanation of what cellular respiration is short but succinct and, in turn, rich in terms, which may require the translator to do further searches for other keywords.

The "Wasser-Lexikon" (Fig. 21) provides information on many areas and terms related to water; in particular water treatment, water pipes, water supply, and the composition of water (substances) for technical use and human consumption. Information on drinking water quality and water testing is presented separately. As noted by the authors, the state of the material in this lexicon is in line with the current state of scientific knowledge. In addition, current waterrelated issues and terms are regularly updated and supplemented.

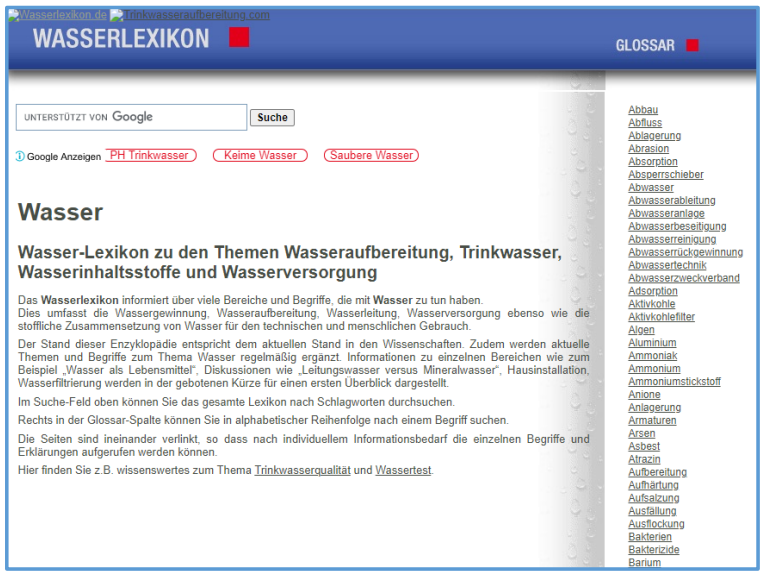

Figure 21 The lexikon "Wasser-Lexikon".

Information on individual issues of a controversial nature such as 'tap water vs. mineral water', water filtration, etc. are presented rather briefly for the sake of initial familiarity.

In the search box at the top, one can search for keywords in the entire lexicon. In the glossary column on the right, one can look up terms in alphabetical order. Sites are linked in such a way that individual terms and explanations can be used according to individual information needs.

By searching for the term "Abwasser" using the glossary, we get a short professional commentary on the concept:

\section{Abwasser}

"Mit dem Begriff Abwasser definiert man in den durch häuslichen, gewerblichen, industriellen, landwirtschaftlichen und sonstigen Gebrauch verunreinigtes und dadurch in seinen natürlichen Eigenschaften verändertes Wasser. Hierzu gehört auch das aus bebauten Gebieten abfließende Niederschlagswasser. Man unterscheidet z. B. Schmutzwasser, Regenwasser, Fremdwasser, Mischwasser, Kühlwasser".

\section{Стічні води}

“Термін “стічні води” використовується для визначення води, яка була забруднена під час побутового, промислового, сільськогосподарського та іншого використання $i$, таким чином, змінила свої природні властивості. Сюди належить також стік дощової води із забудованих територій. Розрізняють, наприклад, брудну воду, дощову воду, воду сусіднього водозбору, змішану вода, вода для охолодження".

Based on the content of the explanation of the term 'Abwasser', the translator can find further explanations of related concepts in the lexicon if necessary, if they are used in the text, he translates. In this way, he or she can overcome thematic difficulties and make maximum use of the terminological resources of the lexicon.

Comparing the printed version of the "Waldschädigende Luftverunreinigungen und Klimawandel" lexicon (Fig. 22 and 23) with its online version, we can conclude that there are several advantages of the online lexicon, which we attribute to:

- a better understanding of the key terms and concepts of the area,

- more data accumulated,

- the possibility of obtaining additional information by searching specialized vocabularies and glossaries, linked by a number of links,

- offer to receive a certain amount of material in PDF format free of charge for printing and use, 
- visual textual material with numerous photos, drawings, tables, graphs,

- continuous updating and up-to-date of the data presented in the entries of the main lexicon and related lexicons and glossaries,

- availability of up-to-date information on the state of the relevant markets.

However, it should be noted that the usefulness of the printed version of the lexicon "Waldschädigende Luftverunreinigungen und Klimawandel" lies in the fact that it contains a lot of tabular and graphical material. This can provide a support for understanding a key concept that is accompanied by a table or a picture.

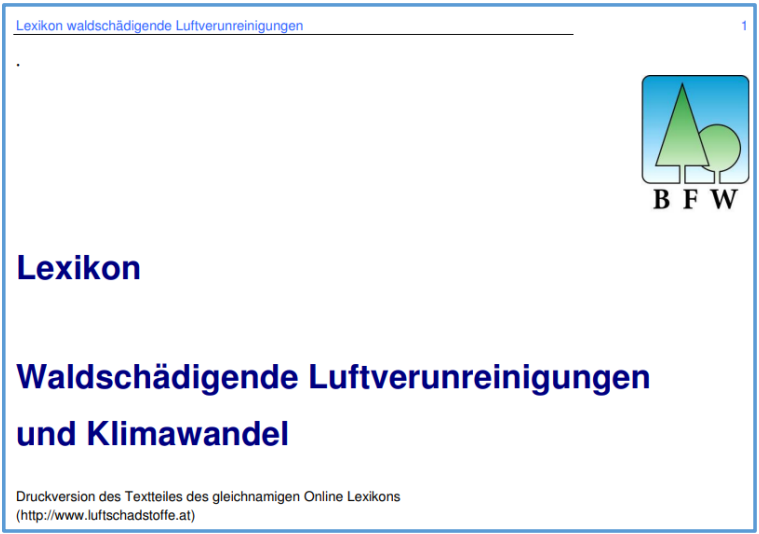

Figure 22 Printed version of the lexicon "Waldschädigende Luftverunreinigungen und Klimawandel".

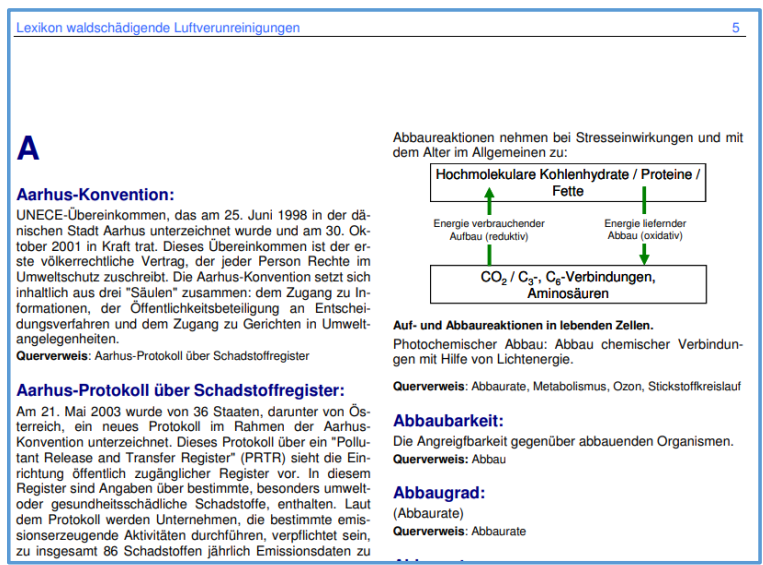

Figure 23 Example of information presentation in the printed version of the lexicon "Waldschädigende Luftverunreinigungen und Klimawandel".

A slightly different kind of lexicon is also noteworthy - "Vergleichendes Lexikon. Wichtige Definitionen, Schwellenwerte und Indices aus den Bereichen Klima, Klimafolgenforschung und
Naturgefahren" ("Comparative Lexicon. Important definitions, thresholds and indicators for the fields of climate, climate impact studies and natural hazards"), the cover page of which is shown in Fig. 24.

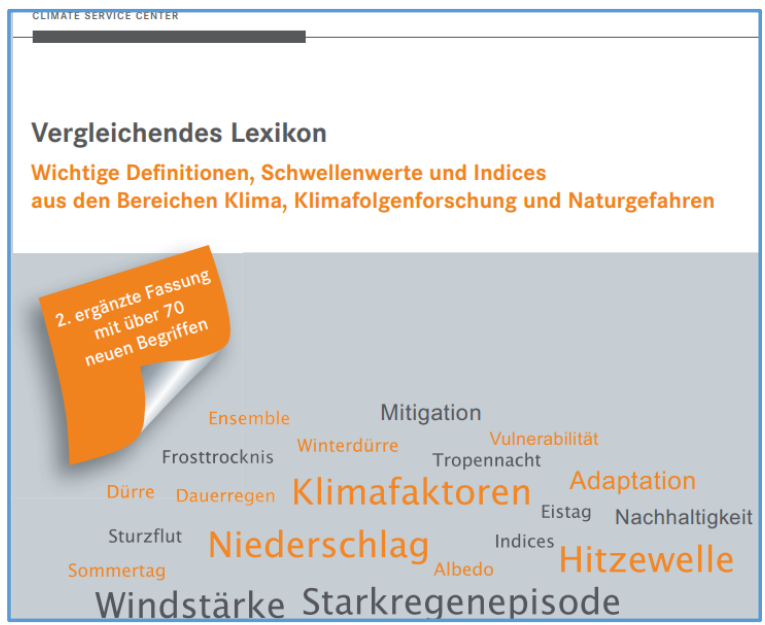

Figure 24 The lexicon "Vergleichendes Lexikon. Wichtige Definitionen, Schwellenwerte und Indices aus den Bereichen Klima, Klimafolgenforschung und Naturgefahren"

As noted by S. Bender [15], one of the authors of the lexicon, many technical terms, such as extreme events or drought, are not clearly defined in the literature. As the need for information for various issues related to climate change increases, so does the need for clear definitions of interdisciplinary technical terms.

The Climate Service Center Germany (GERICS) created a comparative collection of important definitions, limit values, characteristic data and indicators on climate change and its impacts. Its creation was driven by the needs of practice. The lexicon is aimed at employees and project managers in administration, industry and science who deal with climate-related issues in practice. It will also be appropriate for use by those who are not specialists but are interested in climate, providing an opportunity to improve their knowledge of different definitions and methodological approaches. Among these representatives from other fields, there will undoubtedly be translators who, on the one hand, can deepen their knowledge of climate science and, on the other hand, use this lexicon as an important terminological resource that can be fully trusted, since it was created by an official institution.

The lexicon offers a comparison of the variety of possible definitions and characteristics for selected terms from the fields of meteorology, agricultural climatology and hydrogeology. In addition, it shows 
how certain parameters and limitations can be defined with appropriate methods.

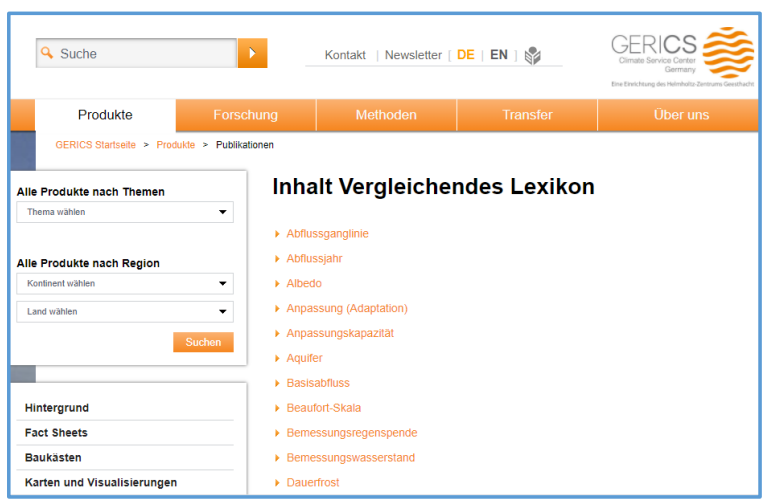

Figure 25 Online version of the lexicon

"Vergleichendes Lexikon. Wichtige Definitionen, Schwellenwerte und Indices aus den Bereichen Klima, Klimafolgenforschung und Naturgefahren”.

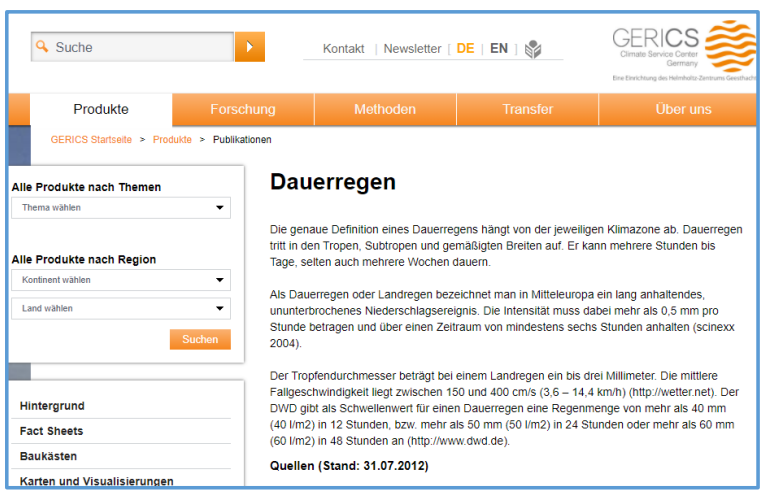

Figure 26 Search results for "Dauerregen" in the online lexicon "Vergleichendes Lexikon. Wichtige Definitionen, Schwellenwerte und Indices aus den Bereichen Klima, Klimafolgenforschung und Naturgefahren".

For the first edition of the lexicon, the terms were selected in two stages. First, those that are frequently used in climate projects, but whose definition depends on the specific project, were selected. In the second stage, the collection has been supplemented with terms for which there are no other definitions, necessary for further understanding. The lexicon also contains crossreferences highlighted separately.

In the second edition, the lexicon was expanded to include several dozen important terms, definitions and indicators in the field of climate impact studies. The main focus of this phase was the description and classification of water levels. In addition, some terms of the first edition have been expanded and revised.

It is worth noting that the selection of terms is constantly being updated with new terms.

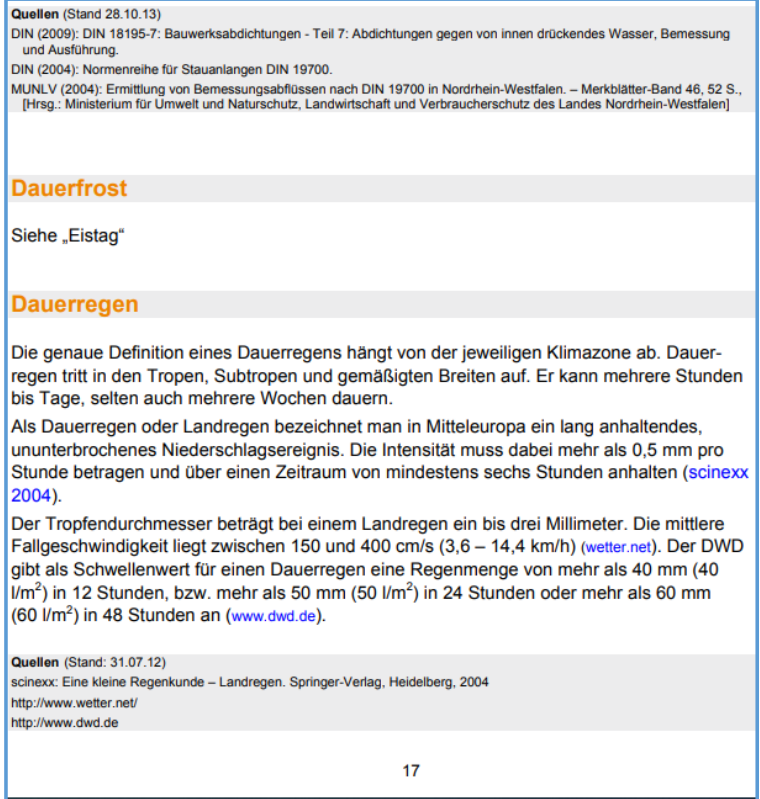

Figure 27 Search results for "Dauerregen" in the printed version of the lexicon "Vergleichendes Lexikon. Wichtige Definitionen, Schwellenwerte und Indices aus den Bereichen Klima,

Klimafolgenforschung und Naturgefahren”.

Comparing the representation of terms and their definitions in the printed and online versions of the lexicon, we can state that they are identical. It is also worth noting that in both versions the sources from which the definitions are taken and the current date of reference to these sources are indicated.

\subsection{Latin lexicon as a mediator of terminology translation}

Among the difficulties encountered by translators when translating texts on agricultural issues is, in particular, the difficulty in finding correspondences for plant names in certain language pairs. If this search is complicated by the lack of analogues in bilingual dictionaries, it is advisable in this case to use a lexicon containing Latin plant names and then find the corresponding Latin names in the respective language into which the translation is made. The scientific names of plants are of great importance, because information about a plant can often only be found if one knows its Latin name [16]. An example of such a lexicon, which contains German and Latin names on different but similarly constructed sites, is shown in Fig. 28 and 29.

As we can see when comparing the Latin and German lexicons, they are similar in structure and therefore using them by a translator to search for terms 
is very easy and quick. Given the fact that in some fields, there are terminological nomenclatures, which completely include all subject names (e.g. plants, animals, chemical elements, etc.), translators can greatly facilitate their work and avoid terminological errors by using Latin lexicons as intermediaries between the source and target languages.

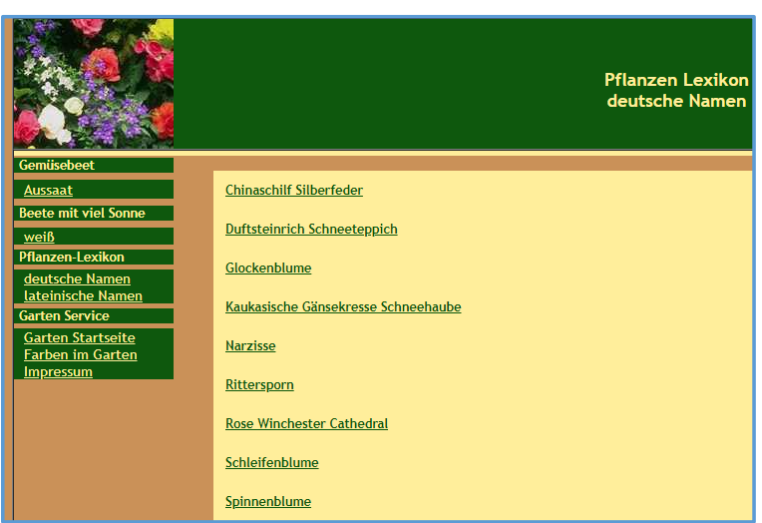

Figure 29 German plant names in the PflanzenLexicon.

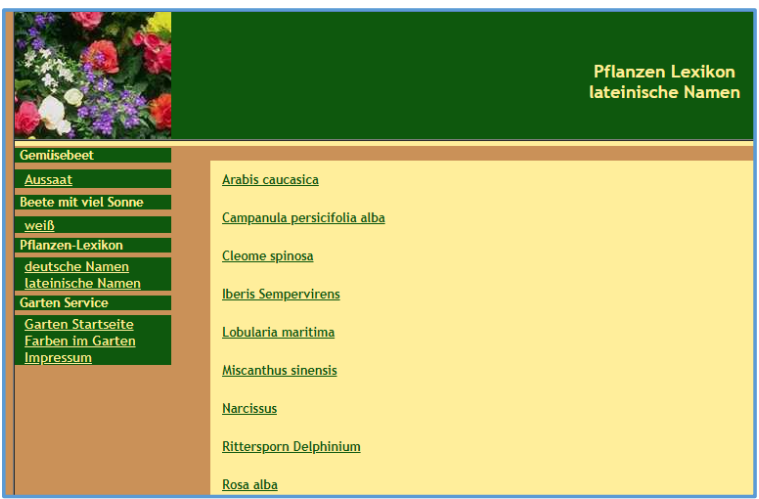

Figure 30 Latin names for plants in the PflanzenLexicon.

\section{CONCLUSIONS}

Having looked at several online lexicons that contain terminology in the agricultural production and environmental protection sector, we can draw the following conclusions:

- online lexicons are a source of domain-specific terminology,

- online lexicons can be used by translators to obtain additional information about the subject of the translation,

- the amount of information in online lexicons is sufficiently large and constantly increasing,
- compared with printed versions, the online versions provide a number of advantages, in particular the continual updating of the vocabularies,

- most online lexicons provide hyperlinks, allowing the translator to find additional information or terminology from other sources.

Thus, online lexicons are a source of sectorspecific terminology and therefore a valuable tool for translators.

\section{REFERENCES}

[1] Duden, German spelling. 28th, completely revised and expanded edition, vol. 1, Dudenverlag, Berlin, 2020.

[2] K. Emmorey, V. Fromkin, The mental lexicon, in F. Newmeyer (Eds.), Linguistics, Cambridge University Press, 1988, pp. 124-149. DOI: https://doi.org/10.1017/CBO9780511621062.00 6J.P.

[3] F. Sowa, Concepts in the Lexicon: Introduction. http://www.jfsowa.com/ontology/lexicon.htm

[4] R.O. Tarasenko, S.M. Amelina, Y.M. Kazhan, O.V. Bondarenko, The Use of AR Elements in the Study of Foreign Languages at the University, CEUR Workshop Proceedings 2731 (2020) 129142.

[5] P. Hanks, The Role of the Lexicon in Linguistic Theory.

DOI: https://doi.org/10.7551/mitpress/9780262018579 .003 .0012

[6] R.O. Tarasenko, S.M. Amelina, A.A. Azaryan, Improving the Content of Training Future Translators the Aspect of Studying Modern CATTools, CEUR Workshop Proceedings 2643 (2020) 360-375.

[7] S. Nielsen, Reviewing printed and electronic dictionaries: A theoretical and practical framework, in: S. Nielsen, S. Tarp (Eds.), Lexicography in the 21st Century, Amsterdam/Philadelphia, 2009, pp. 23-41.

[8] A. Davies, C. Elder (Eds.), The handbook of applied linguistics, Blackwell, Malden, MA, 2004.

[9] H. Bejoint. Dictionaries: The Art and Craft of Lexicography, International Journal of Lexicography 15 (2002) 169-173. 
[10] D. Singleton, Language and the Lexicon. An Introduction, Routledge, 2000.

[11] Wiki-Agrar-Lexikon. https://www.topagrar.com/management-undpolitik/news/von-abdrift-bis-zwischenfrucht9588484.html

[12] K. Baldenhofer, Lexicon of the agricultural area, Gotha, 1999, S. 215. https://www.natur-undlandschaft.de/de/news/lexikon-des-agrarraumsals-internet-version-frei-zuganglich-1595

[13] M.G. Raupp, Agricultural lexicon with the most important terms for agriculture in the European environment, Madora $\mathrm{GmbH} \&$ Lörrach International e.V. Vereinsregister, Lörrach, 2017.

[14] S. Smidt, Lexikon. Air pollution harmful to forests and climate change. Print version of the text part of the online lexicon of the same name, 2011.

[15] S. Bender, M. Schaller, Comparative Lexicon. Important definitions, threshold values and indices from the areas of climate, climate impact research and natural hazards, Climate Service Center, 2014.

[16] D. Dittfeld. Botanical plant names - origin and meaning.

https://www.gartentipps.com/botanischepflanzennamen.html 